\title{
RISK FACTORS AND MANAGEMENT OF ANEMIA IN PREGNANCY
}

\author{
Saleha Sadeeqa, Samia Habib, Mubashara Saeed, Sania Shahid, Saba ljaz, Anum Javaid, Sumera Latif \\ Institute of Pharmacy, Lahore College for Women University, Lahore - Pakistan
}

\begin{abstract}
Objective: This study was aimed to assess the dietary and socioeconomic factors associated with anemia in pregnancy and its management.
\end{abstract}

Materials and Method: A cross-sectional, descriptive study design was adapted using convenience sampling technique, involving 200 pregnant anemic women, during the period June-2018 to August- 2018 in different private and public sector hospitals of Punjab Pakistan. Data was collected through structured questionnaire and analyzed using SPSS version 20.

Results: Anemia was more prevalent (47.5\%) among women aged 25-30 years. Significant association was found between gestational period and respondent' age $(p=0.021)$ \& educational level $(p=0.000)$. Hemoglobin level of patients was significantly associated with educational level $(p=0.000)$, location $(p=0.05)$ while tea/coffee consumption was significantly associated with educational level $(p=0.000)$ \& location $(p=0.022)$, protein diet consumption was significantly associated with age $(p=0.001)$, educational level $(p=0.000)$ \& location $(p=0.000)$, vegetables \& fruits consumption was significantly associated with educational level $(p=0.003)$ and finally treatment option was significantly associated with age $(p=0.015)$, education level $(p=0.000)$ and location $(p=0.000)$.

Conclusion: The study concluded that pregnant women of age group 25-30 years were at high risk of anemia. It is more prevalent in uneducated women and those living in rural areas. Healthy and fresh balanced diet rich in iron is recommended for health and good growth of the developing baby.

Keywords: Anemia, Pregnant, Hemoglobin, Mortality, Management

This article may be cited as: Sadeeqa S, Habib S, Saeed M, Shahid S, ljaz S, Javaid A, Latif S. Risk factors and management of anemia in pregnancy. J Med Sci 2021 July;29(3):108-111

\section{INTRODUCTION}

Anemia in pregnancy is common worldwide issue regarding public health and is characterized as hemoglobin levels less than $11 \mathrm{~g} / \mathrm{dl}$ during the first and third trimester, and less than $10.5 \mathrm{~g} / \mathrm{dL}$ during the second trimester ${ }^{1,2}$. It affects more than 56 million women globally ${ }^{3}$. According to WHO survey, more than half of the pregnant women are suffering from this disease ${ }^{4}$ and is common among females aged 25-30 years ${ }^{5}$. Education reduces the risk of pregnancy anemia because of better knowledge on eating nutritious food ${ }^{6,7}$. Although it is common among developing countries, yet developed countries are not free from it; with high prevalence among rural areas than in urban areas $^{8}$.

Physiological adaptation during pregnancy causes hemoglobin dilution that leads to anemia ${ }^{9}$. Risks of iron deficiency anemia increases during second and third trimester, ${ }^{10}$ that can lead to the premature birth, death of

\section{Correspondence}

Dr. Saleha Sadeeqa

Institute of Pharmacy, Lahore College for Women University, Lahore - Pakistan

Email: salehasadeeqa@gmail.com

Cell: +92-305-4122345

Date received: $\quad 07-11-2020$

Date revised: $\quad 06-08-2021$

Date accepted: $08-08-2021$ both baby and mother, perinatal mortality, growth restriction and low birth weight ${ }^{11-13}$. Pregnancy related anemia is observed to be common in third trimester ${ }^{14}$. In reference to previous studies lowest hemoglobin level observed during pregnancy was $3.5 \mathrm{gm} / \mathrm{dl}$, highest was $12.9 \mathrm{gm} / \mathrm{dl}$ and average level were $9.5 \mathrm{gm} / \mathrm{dl}$ in a previous study ${ }^{5}$.

Anemia is a multifactorial disease, such as Iron, folate, VitB12 deficiency, parasitic infections and malaria observed to be the primary causes of anemia ${ }^{15,16}$ secondary to low education level, teenage pregnancy, poor socioeconomic status and short inter pregnancy interval ${ }^{17}$. Genetic factors and poor hygiene are other contributing factors ${ }^{18}$.

Effective management of pregnancy anemia includes treatment of the underlying causes, restoration of the hemoglobin concentration, prevention and treatment of complications. This can be achieved with intake of healthy and balanced diet rich with iron and vitamins (meat, green vegetables, fruits etc) and prohibit intake of substances that reduce iron absorption (tea, coffee etc) ${ }^{19}$. Many studies have supported the strategy of supplementing pregnant women with iron and folic acid to increase the hemoglobin levels ${ }^{20}$. Treatment of pregnancy anemia includes intake of required supplements in accordance with diagnosis made. Most recommended supplements include oral elemental iron between 65-200 mg per day. 
When oral iron cannot be tolerated or is ineffective then IV iron replete iron stores ${ }^{21,22}$. Despite all, it is still a common cause of mortality and morbidity. This study is aimed to assess dietary and socioeconomic factors associated with pregnancy anemia and its management among pregnant females.

\section{MATERIALS AND METHODS}

A cross-sectional, descriptive study design was adapted using convenience sampling technique, during the period June-2018 to August- 2018. Data was collected from the department of Obstetrics and Gynecology of different private and public sector hospitals including Services hospital, Jinnah hospital, Lady Atchison hospital of Punjab-Pakistan. Data was collected through structured questionnaire and analyzed by using SPSS version 20 .

Informed consent was obtained from all of the women who volunteered to participate. A structured questionnaire was designed to gather information which included questions related to patient's demography, diagnosis of anemia, risk factors, management and treatment of pregnancy anemia. Majority of the women completed their questionnaire themselves, while some were assisted. Data was analysed using SPSS version 20. Statistical significance was determined using chi square test $p \leq$ 0.05 was considered as statistically significant. Study was approved from Institute of Pharmacy, Lahore College for Women University. Lahore. Permission to access patients was obtained from the gynecology and obstetrics department of the respective hospitals.

\section{RESULTS}

Results regarding patient demographics are presented in Table-1, which shows that $47.5 \%$ of the women were between the ages of $25-30$ years, $33 \%$ females were having gestational age 21-25years, $11.5 \%$ females were found with gestational age $>30 y$ rs. Results for education level showed that $52 \%$ females were having primary education, $24 \%$ females were having secondary education, $16 \%$ females were having tertiary education, and only $8 \%$ of patients were not having any formal education. $32.5 \%$ female were from rural area and $67.5 \%$ females were from urban area. Association of gestational period with demographic characters is displayed in Table-2, which showed that $7.5 \%$ of females were in 1 st trimester of pregnancy, $16.5 \%$ females were in 2nd trimester, and $76.5 \%$ females were in 3rdtrimester of pregnancy. Significant association was found between gestational period and respondent' age $(p=0.021)$ and educational level $(p=$ 0.000 ). Association of hemoglobin level with demographic characters is displayed in Table-3, which showed that $75.5 \%$ females were having $\mathrm{Hb}$ level ranging $\mathrm{b} / \mathrm{w} 7-10 \mathrm{mg} /$ dl, $22.5 \%$ of females were having $\mathrm{Hb}$ level $>10 \mathrm{mg} / \mathrm{dl}$, and only $2 \%$ were having $\mathrm{Hb}$ level b/w 3-6mg/dl. Significant association was found between $\mathrm{Hb}$ level of patients and education level $(p=0.000)$, location $(p=0.05)$.

Association of dietary habits with demographic characters is displayed in Table- 4 , which showed that $81 \%$ females were taking tea/coffee and significant association was found between tea/coffee consumption and education level $(p=0.000)$ and location $(p=0.022)$. A total of $18 \%$ females were taking protein diet and significant association was found between protein diet consumption and age $(p=0.001)$ education level $(p=0.000)$ and location $(p=0.000)$. A total of $74 \%$ females were taking vegetables and fruits and significant association was found between vegetables and fruits consumption and education level $(p=0.003)$. Association of treatment options with demographic characters is displayed in Table-5, which showed that $41.5 \%$ patients were recommended for treatment with iron supplements \& improved diet both, 6.5\% were taking oral supplements, $27 \%$ were administered with iron IV, $23 \%$ were advised to improve diet, and only $22 \%$ patients were recommended for blood transfusion. Significant association was found between treatment options and age $(p=0.015)$, education level $(p=0.000)$ and location $(p=0.000)$.

\section{DISCUSSION}

Pregnancy anemia being common and prevalent problem was observed to be common among the females having age ranging between 26-30years. Results seem to be in accordance with the results of previous studies5. The results regarding effect of education on prevalence of pregnancy anemia showed that it was more prevalent in less educated or uneducated women, previous studies supported this outcome that this condition is prevalent among uneducated females ${ }^{5,6}$.

Results further showed that $76.5 \%$ females were in 3rd trimester, $16.5 \%$ in 2nd trimester, and $7.5 \%$ in 1 st

Table 1: Patient's demographics

\begin{tabular}{|c|c|c|}
\hline Variable & Frequency $(\mathrm{N}=200)$ & Percentage \% \\
\hline \multicolumn{3}{|c|}{ Gestational age of patient } \\
\hline $16-20 y r s$ & 16 & 8 \\
\hline $21-25 y r s$ & 66 & 33 \\
\hline $26-30 y r s$ & 95 & 47.5 \\
\hline$>30 \mathrm{yrs}$ & 23 & 11.5 \\
\hline \multicolumn{3}{|c|}{ Level of education } \\
\hline $\begin{array}{l}\text { No formal } \\
\text { education }\end{array}$ & 16 & 8 \\
\hline Primary & 104 & 52 \\
\hline Secondary & 48 & 24 \\
\hline Tertiary & 32 & 16 \\
\hline \multicolumn{3}{|c|}{ Area } \\
\hline Urban & 135 & 67.5 \\
\hline Rural & 65 & 32.5 \\
\hline
\end{tabular}

J Med Sci 2021 July;29(3):109-111 
Risk Factors And Management Of Anemia In Pregnancy

Table 2: Association of gestational period with demographic characters

\begin{tabular}{|c|c|c|c|}
\hline Variable & Frequency (\%) & $\begin{array}{c}\text { Demographic } \\
\text { Character }\end{array}$ & $\mathrm{P}$-Value \\
\hline 1st trimester & $15(7.5)$ & Age & 0.021 \\
\hline 2nd trimester & $33(16.5)$ & Education level & 0.000 \\
\hline 3rd trimester & $152(76.5)$ & Area & 0.706 \\
\hline
\end{tabular}

Table 3: Association of hemoglobin level with demographic characters

\begin{tabular}{|c|c|c|c|}
\hline Variable & Frequency (\%) & $\begin{array}{c}\text { Demographic } \\
\text { Character }\end{array}$ & $\mathrm{P}$-Value \\
\hline $3-6 \mathrm{mg} / \mathrm{dL}$ & $4(2)$ & Age & 0.640 \\
\hline $7-10 \mathrm{mg} / \mathrm{dL}$ & $151(75.5)$ & Education level & 0.000 \\
\hline$>10 \mathrm{mg} / \mathrm{Dl}$ & $45(22.5)$ & Area & 0.05 \\
\hline
\end{tabular}

Table 4: Association of dietary habits with demographic characters

\begin{tabular}{|c|c|c|c|}
\hline Variable & Frequency (\%) & $\begin{array}{l}\text { Demographic } \\
\text { Character }\end{array}$ & $\mathrm{P}$-Value \\
\hline \multicolumn{4}{|c|}{ Tea consumption } \\
\hline Yes & $162(81)$ & Age & 0.164 \\
\hline No & $38(19)$ & Education level & 0.000 \\
\hline & & Location & 0.022 \\
\hline \multicolumn{4}{|c|}{ Protein diet consumption: } \\
\hline Yes & $36(18)$ & Age & $0=.001$ \\
\hline No & 164(82) & Education level & $0=.000$ \\
\hline & & Location & 0.000 \\
\hline \multicolumn{4}{|c|}{ Vegetables and fruits consumption: } \\
\hline Yes & $148(74)$ & Age & 0.996 \\
\hline No & $52(26)$ & Education level & 0.003 \\
\hline & & Location & 0.127 \\
\hline
\end{tabular}

Table 5: Association of treatment options with demographic characters

\begin{tabular}{|c|c|c|c|}
\hline $\begin{array}{c}\text { Treatment } \\
\text { options }\end{array}$ & Frequency (\%) & $\begin{array}{c}\text { Demographic } \\
\text { Character }\end{array}$ & P-Value \\
\cline { 1 - 2 } $\begin{array}{c}\text { Iron supple- } \\
\text { ments }\end{array}$ & $13(6.5)$ & $\begin{array}{c}\text { Age } \\
\text { Education level } \\
\text { Location }\end{array}$ & $\begin{array}{l}0.015 \\
0.000 \\
0.000\end{array}$ \\
\cline { 1 - 2 } Iron IV & $54(27)$ & \\
\cline { 1 - 2 } $\begin{array}{c}\text { Improving } \\
\text { diet }\end{array}$ & $46(23)$ & \\
\cline { 1 - 2 } $\begin{array}{c}\text { Iron sup- } \\
\text { plements \& } \\
\text { Iron IV }\end{array}$ & $43(21.5)$ & \\
\cline { 1 - 2 } $\begin{array}{c}\text { Blood trans- } \\
\text { fusion }\end{array}$ & $44(22)$ & \\
\hline
\end{tabular}

trimester. This result is supported by previous studies that showed increased chances of pregnancy anemia during 2nd and 3 rdtrimester ${ }^{14}$. Results regarding hemoglobin level showed that $2 \%$ females were having $\mathrm{Hb}$ level within $3-6 \mathrm{mg} / \mathrm{dl}, 75.5 \%$ were having within $7-10 \mathrm{mg} / \mathrm{dl}$, and $22.5 \%$ were having greater than $10 \mathrm{mg} / \mathrm{dl}$. This outcome is sup- ported by the previous research ${ }^{5}$.

Assessment of dietary intake of patient showed that anemic condition is prevalent among coffee/tea takers and is prevented by eating balanced diet, consisted of proteins, vegetables and fruits findings are supported by other studies $19.27 \%$ of patients were recommended for iron administration through IV route, $23 \%$ patients were advised to improve diet, $21.5 \%$ patients were advised to take iron supplements with improvement of their diet, 22\% were recommended for blood transfusion. These findings are consistent with recommended treatment methods $^{20,21,22}$

\section{CONCLUSION}

Anemia is global health condition affecting more than half of the pregnant females. According to the present findings it is concluded that females during 2nd and 3rd trimester are at verge of developing anemia. Iron deficiency is considered as the primary reason. This condition is prevalent among the females of reproductive age were majority of them were uneducated. Intake of healthy balanced diet, with iron supplements before and during pregnancy tends to control the severity of condition.

\section{REFERENCES}

1. Jaleel $R$, Khan A. Severe anemia and adverse pregnancy outcome. J Surg Pak Inter. 2008; 13:147-50.

2. Roy, Pavord S. The management of anemia and haematinic deficiencies in pregnancy and post-partum. Trans Med (Oxford, England), 2018; 28 (2): 107-116.

3. Balarajan $\mathrm{Y}$, Ramakrishnan U, Ozaltin E, Shankar AH, Subramanian SV. Anemia in low-income and middle-income countries. The Lancet, 2011; 378 (9809):21232135.

4. Lone FW, Qureshi RN, Emmanuel F. Maternal anemia and its impact on perinatal outcome in a tertiary care hospital in Pakistan. East Mediter Health J. 2004; 10:801-7.

5. Shumaila Noreen, Faisal Nouroz, Shakeel Ahmad, Sajid Khan. Prevalence of Anemia in Pregnant Women of District Abbottabad. Pak J of Clin Biomed Res. 2014; 2 (2): $12-16$

6. Lozano R, Naghavi M, Foreman K, et al. Global and regional mortality from 235 causes of death for 20 age groups in 1990 and 2010: A systematic analysis for the global burden of disease study 2010. The Lancet. 2012; 380(9859):2095-2128.

7. Gautam C, Sahal, Sekhri K, Saha P. Iron deficiency in pregnancy and rationality of iron supplements prescribed. J Med Sci. 2008; 10(12):283.

8. Cohan JH, Hass JD. Hemoglobin concentration factors for estimating the prevalence of Iron Deficiency Anemia in pregnant women residing at high altitudes in Bolivia. Pan Amer J Public Health 1999; 6(6):392-399.

9. Kozuma S. Approaches to Anemia in pregnancy. Japan Med Assoc J. 2009; 52(4):214-218. 
10. Stephansson O, Dickman PW, Johansson A, Cnattingius $S$. Maternal hemoglobin concentration during pregnancy and risk of stillbirth. JAMA. 2000; 284:2611-2617.

11. Alwan N. A., Hamamy $H$. Maternal iron status in pregnancy and long-term health outcomes in the offspring. $J$ Pedia Genet. 2015; 4(2):111-123.

12. Lozoff B, Brittenham GM, Wolf AW. Iron deficiency Anemia and iron therapy. Effects on infant developmental test performance. Pediatrics 1987; 79: 981-995.

13. Lone FW, Qureshi RN, Emmanuel F. Maternal anaemia and its impact on perinatal outcome in a tertiary care hospital in Pakistan. East Mediter Health J. 2004; 10(6):801-807.

14. Allen LH. Anemia and iron deficiency: effects on pregnancy outcome. The Amer $\mathrm{J}$ Clinical Nutri . 2000;71(5):1280S-1284S.

15. Antelman G, Msamanga GI, Spiegelman D, et al. Nutritional factors and infectious disease contribute to anemia among pregnant women with human immunodeficiency virus in Tanzania. J Nutri. 2000;130(8):1950-1957.

16. Tolentino K, Friedman JF. An update on Anemia in Less Developed Countries. The Amer J Tropic Medic and Hygiene. 2007;77(1):44-51.

17. Sagili H, Pramya N, Prabhu K, Mascarenhas M, Reddi Rani P. Are teenage pregnancies at high risk? A comparison study in a developing country. Archives Gynec and Obste. 2012; 285: 573-577.

18. Seshadri S. Prevalence of micronutrient deficiency particularly of iron, zinc and folic acid in pregnant women in South East Asia. British J of Nutrition. 2001; 85(suppl 2): S87-92.

19. Weiss G. Anemia of chronic disorders: new diagnostic tools and new treatment strategies. Seminars in Hematology. 2015; 52(4):313-320.
20. Kalaivani K. Prevalence and consequences of anemia in pregnancy. Indian J Medic Res. 2009; 130: 627-33.

21. Pavord, Sue; Myers, Bethan; Robinson, Susan; Allard, Shubha; Strong, Jane; Oppenheimer, Christina; British Committee for Standards in Haematology UK guidelines on the management of iron deficiency in pregnancy. British J Haematology. 2012; 156 (5): 588-600

22. Breymann, Christian "Iron Deficiency Anemia in Pregnancy". Seminars in Hematology. 2015; 52 (4): 339-347.

CONFLICT OF INTEREST: Authors declare no conflict of interest

GRANT SUPPORT AND FINANCIAL DISCLOSURE: NIL

\section{AUTHOR'S CONTRIBUTION}

Following authors have made substantial contributions to the manuscript as under

Sadeeqa S: Concept and Design

Shahid S: $\quad$ Acquisition and critical review

Habib S: $\quad$ Analysis and interpretation of data

Saeed M: $\quad$ Final approval

ljaz S: Data collection

Javaid A: Proof reading

Latif S: Data collection and review

Authors agree to be accountable for all aspects of the work in ensuring that questions related to the accuracy or integrity of any part of the work are appropriately investigated and resolved. 